\title{
$\mathrm{PH} 91_{\text {panorama }}$
}

\section{Un proyecto del Museu Marítim de Barcelona: sesiones de identificación de fotografía marítima}

\begin{abstract}
Los trabajos de documentación en fotografía naval requieren de unos conocimientos muy especializados. Desde hace años el Museu Marítim de Barcelona lidera un proyecto de identificación fotográfica que tiene su excelencia en una singular apuesta: la invitación a participar en esta actividad a todas aquellas personas amantes de la fotografía naval, tanto civil como militar, bien sean expertas o aficionadas. Desde 2013 esta interesante iniciativa fundamentada en un trabajo transversal y colaborativo ha ido tomando forma hasta consolidar dos grupos de trabajo complementario: el Laboratorio de expertos y las Sesiones de identificación.
\end{abstract}

Silvia Dahl Termens | Museu Marítim de Barcelona

URL de la contribución <www.iaph.es/revistaph/index.php/revistaph/article/view/3910>

\section{Un archivo fotográfico sobre el mar}

El Museu Marítim de Barcelona custodia más de 250.000 fotografías (DAHL TERMENS, 2012) especializadas en el mar. La rica variedad temática implica cierta complejidad para la documentación. El conocimiento del artefacto fotográfico (técnica, procesos) y la especialización en la temática son imprescindibles al catalogar este material.

\section{Antecedentes}

Los trabajos de documentación en la fotografía naval son apasionantes. Requieren unos conocimientos adquiridos con los años, tras la observación de miles de fotografías, el acceso a fuentes escritas y orales, y el contrastar opiniones con los expertos. Este último aspecto ha sido el que, ya en los primeros años del 2000, suscitó la necesidad de invitar a la participación externa, apostando por una manera de trabajar transversal, que contaba con los propios recursos del museo, pero también con la participación de colaboradores y voluntarios externos. De manera gradual y progresiva se fue consolidando un grupo integrado por especialistas de referencia en el país y amantes de la fotografía marítima. Teníamos la voluntad de resolver lagunas documentales $\mathrm{y}$, al mismo tiempo, ofrecer un espacio a un colectivo muy especializado y comprometido, que iban en la misma dirección que nuestra misión. Sin duda, un proyecto en el que fue decisiva la mente visionaria de Camil Busquets i Vilanova (1936-2016), fotógrafo, publicista naval, inestimable colaborador y "puente" entre los especialistas del sector.

\section{Desarrollo del proyecto}

La ejecución del proyecto arranca en abril de 2013 cuando se convocó la primera sesión de identificación y se invitó a expertos en la materia. La buena acogida y la petición por parte de los asistentes de nuevas convocatorias, nos hizo establecer una programación anual de 4 sesiones de identificación de fotografía marítima. Más aún: entre los asistentes, un reducido grupo empezó a acudir semanalmente al museo para ayudar en la documentación. De esta manera el proyecto evolucionó hacia dos grupos de trabajo que se complementaban: además de las Sesiones, el Laboratorio de expertos en fotografía naval, que cada semana contrasta y completa la información de los registros sobre barcos mercantes y militares.

El Laboratorio de expertos en fotografía naval realiza una valiosísima investigación que completa los datos más básicos de la ficha de catalogación, corrige errores y confecciona una sinopsis histórica de muchos de los barcos retratados como, por ejemplo, el lugar de construcción, cronología, cambios de nombre del barco y/o armador, accidentes $u$ otros datos significativos. Esta información se introduce de manera sistemática en una ficha básica especial creada a partir de la selección de algunos de los descriptores de la base de datos ("Categoría Fotografia" del programa de gestión de colecciones MuseumPlus).

Las Sesiones de identificación de fotografía marítima se programan en 4 sesiones anuales (una por trimes- 


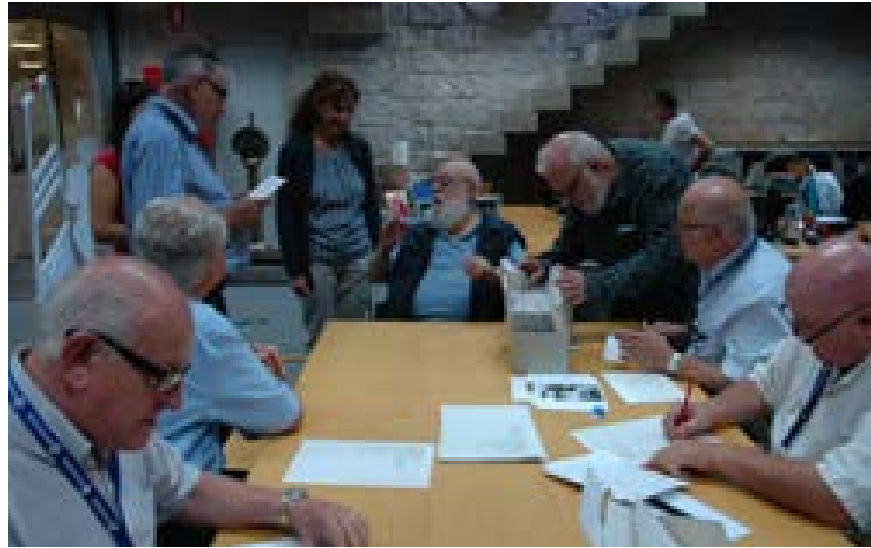

Laboratorio de expertos en fotografía naval | foto J. Matamala

tre) centradas en una selección de unas 25 imágenes que contienen cierta o mucha complejidad (nombre del barco, lugar de la foto, cronología, autor, entre otros datos), o que dan pie a debate por la singularidad de lo retratado. Esta selección incluye barcos mercantes, de pasaje o militares, pero se están introduciendo las categorías de pesca y náutica deportiva, para documentar también temáticas que conforman nuestras colecciones fotográficas y de las que también es necesario ampliar conocimientos. El Laboratorio de expertos selecciona un grupo de fotografías que recoge en un documento, con preguntas a investigar. Las semanas previas a la sesión se envía este documento al grupo, lo que permite buscar información y, en caso de no poder asistir a la reunión, enviar por correo-e. las opiniones contrastadas. También se publicita en las redes sociales del museo (web corporativa, Newsletter, blog del archivo fotográfico, Facebook) invitando al público interesado. Durante las sesiones se registran todas las anotaciones y referencias bibliográficas/documentales en la ficha básica de catalogación.

Sin duda la actividad ha adquirido tal impulso que está permitiendo no sólo que se documenten fotografías del museo, sino también incorporar a las sesiones imágenes que provienen de colecciones particulares, enriqueciendo sin duda las reuniones, al tiempo que los investigadores encuentran en este espacio de intercambio un lugar de debate y de resolución de dudas. También el Laboratorio se ha convertido en un eficiente equipo de trabajo. A la vista del gran potencial del proyecto $y$

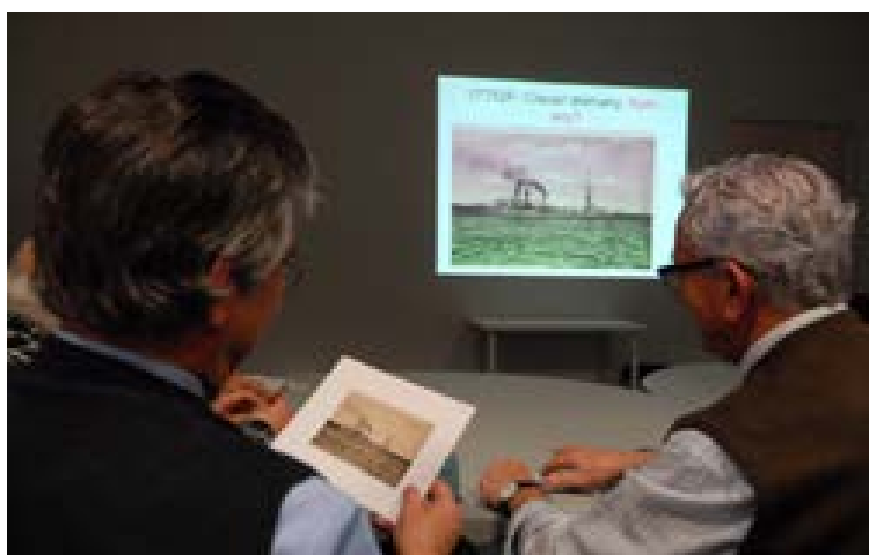

Sesión de identificación de fotografía marítima | foto L. Covarsí

las ganas de compartir y aprender, estamos invitando a expertos/amantes de la foto naval de otras entidades y museos especializados del país, a fin de que se beneficien de esta actividad al tiempo que la enriquecen con su participación (presencial o mediante videoconferencia).

\section{Conclusiones}

Este proyecto nace de una doble misión: por un lado de la necesidad del museo de documentar con rigor las fotografías, sirviéndose de la generosa y desinteresada ayuda de expertos $y$, por otro, de la posibilidad insitucional de ofrecer a investigadores, coleccionistas y a amantes de la fotografía naval, un espacio en el que reunirse e intercambiar conocimientos e información.

Nos gustaría ampliar los temas de debate a los grandes veleros, la pesca y los deportes náuticos, por lo que extendemos la invitación a a colaborar a todas aquellas personas interesadas en estas cuestiones. Confiamos en que este trabajo continue siendo útil para los colectivos del sector marítimo y, en definitiva, para la sociedad, pues se trata de una plataforma de intercambio de una fotografía muy especializada, y que está al servicio de todos.

\section{BIBLIOGRAFÍA}

- DAHL TERMENS, S. (2012) Històries de mar. Les col leccions fotogràfiques del Museu Marítim de Barcelona. Barcelona: Museu Marítim de Barcelona, 2012 